\title{
LENGYEL ÉS MAGYAR FIATALOK BORFOGYASZTÁSA
}

\author{
Baglyas Ferenc ${ }^{1^{*}}$, Bronisław Brzozowsk ${ }^{2}$, Lakner Zoltán ${ }^{3}$, \\ ${ }^{1}$ NJE Kertészeti és Vidékfejlesztési Kar, Kertészeti Tanszék 6000 Kecskemét, Izsáki út 10. \\ Tel.: +36-76-516-340, baglyas.ferenc@kvk.uni-neumann.hu \\ ${ }^{2}$ Akademia Rolnicza, Katedra Ekonomiki i Organizacji Rolnictwa, 31-120 Kraków, Al. Mickiewicza 21, \\ Tel.: +48-12-634-09-49, rrbrzozo@ @cyf-kr.edu.pl. \\ ${ }^{3}$ SZIE Gazdaság- és Társadalomtudományi Kar, Agrobiznisz Intézet, Élelmiszerlánc-management tanszék \\ 2100 Gödöllő, Páter Károly utca 1. Tel.: +36-28-522-000, info@gtk.szie.hu \\ https://doi.org/10.47833/2020.3.AGR.008
}

\section{Kulcsszavak:}

borfogyasztás

kérdőíves megkérdezés

lengyel és magyar agrár hallgatók

fogyasztás gyakorisága

bor íz, szőlőfajta preferencia

\section{Keywords:}

wine consumption questionnaire survey

Polish and Hungarian students wine taste, variety preference

\section{Cikktörténet:}

Beérkezett 2020. október 10. Átdolgozva 2020. október 31. Elfogadva 2020. november 5 .

\section{Összefoglalás}

Egy kérdőíves felmérés keretében összehasonlítottuk a lengyel és a magyar agrár felsőoktatásban tanuló fiatalok borfogyasztási szokásait. A mintaelemek eltérő száma miatt relatív gyakoriságokkal számoltunk. A felmérés a borfogyasztás gyakoriságára, a borok leginkább preferált édességi szintjének meghatározására, a legkedveltebb termőhelyre, valamint a fogyasztás elmaradásának okainak feltárására vonatkozott. A kapott eredmények szerint a válaszadók aránya alapvetően azonos, de a fogyasztás gyakoriságát tekintve jelentős különbségek vannak. A lengyel fiatal diákok inkább a félszáraz és félédes borokat részesítik előnyben. Leginkább francia és olasz borokat vásárolnak, de ismerik a magyar borokat is. A lengyel diáklányok általában elutasítják a bor és más alkoholtartalmú italok fogyasztást.

Abstract
We compared by direct questionnaires the wine consuming
habits of young people attending Polish and Hungarian agrarian
higher education. As a consequence of the divergent number of
sample elements, relative frequencies were calculated. The
survey concerned the frequency of wine consumption, the
determination of the mostly preferred sweetness level of wines,
the best favoured growing site as well as the exploration of the
causes of non-consumption. According to the results obtained,
the proportion of wine respondents of the two countries are
basicly the same, but regarding the frequency of consumption
there are substantial differencies. Polish young students avoid
taste extremes and prefer semi dry and semi sweet wines. They
are buying mostly French and Italian wines but they are also
familiar with the Hungarian wines. Polish girl students generally
reject wine consumption because of their negative discreetion
of alcohol. (original abstract)n a few sentences, the author(s)
should write the aims of the paper.

\section{Bevezetés}

A '90-es évek gazdasági- és társadalmi változásai hatást gyakoroltak a magyar élelmiszeripar alakulására. Csökkent a mezőgazdaság aránya a bruttó nemzeti termelésben. A tulajdonosi

\footnotetext{
* Corresponding author Email: baglyas.ferenc@kvk.uni-neumann.hu
} 
struktúra teljesen átalakult, 2005-ben az élelmiszergazdálkodásban müködő töke 38\%-a már külföldi tulajdonban müködött.

Magyarország kétes értékủ világelsősége a megtermelt bor exportra kerülésének arányát illetően megszűnt a KGST és a Szovjetunió összeomlásával. Az olcsó kannás borok bevezetése és a decentralizált borkereskedelem kialakulása magángazdák ezreit mentette meg a pénzügyi csődtől. A kereslet azonban kettényílt: a legolcsóbb és a legdrágább termékek fogyasztásával kapcsolatosan nyilvánul meg a legnagyobb igény.

A nemzetközi globalizáció és Magyarország integrációja az EU-ba újabb kihívásokat jelent a magyar boriparnak. A versenyképesség fokozása, az elvesztett piacok visszaszerzése többlet információt feltételez. A döntéshozatalok eredményességét alapvetően meghatározzák a piaci ismeretek.

A cikkünkben két kelet-európai ország, Magyarország és Lengyelország fiataljainak borfogyasztás-magatartását elemezzük. Lengyelország, mint bort zömmel importáló ország, a történelem során mindig jelentős exportpiaca volt hazánknak. Ezt a piacot elveszítettük, de visszanyerésére erőfeszítéseket kell tenni.

A fiatalok a jövő potenciális fogyasztói. Ezért is tartottuk fontosnak összehasonlítani a két ország azonos célcsoportjait.

\section{Irodalmi áttekintés}

Levitt szerint (1) az emberek mindenhol jó minőségű, megbízható és elérhető árú terméket keresnek, (2) az országok közötti különbségek a történelmi múlt termékei és fokozatosan csökkenő tendenciát mutatnak, (3) a közös márka, csomagolás és kommunikáció jelentős költségcsökkenést jelent azon versenytársaknak, akik csak egy szük piaci szegmens számára termelnek. Sokan nem értenek teljes mértékben egyet Levitt-el. Többük, tekintélyes akadémikusok azt állítják, hogy nem minden termék standardizálható. Nincs arra nézve sem bizonyíték, hogy a fogyasztók hasonulnának egymáshoz [4].

Anson et. al. reprezentatív felmérést végzett Franciaországban az 1980, 1985 és 1990-es években, hogy a fogyasztói magatartás megismerésével magyarázatot nyerjen a borfogyasztásban tapasztalható visszaesésre és egy trendet vázolhasson fel az elkövetkezendő időszakra vonatkozóan. A legnagyobb változás a fogyasztás gyakoriságában tapasztalható. A bort soha-sem fogyasztók aránya az 1980-as évi 32,5\%-ról 1990-re 50,7\%-ra nőtt. A visszaesés különösen a nő körében jelentős. Minden korcsoportban megfigyelhető a fogyasztás csökkenése [1].

A Szőlészeti és Borászati Kutató Intézet 1988-ban két felmérés keretében próbált választ kapni a borfogyasztók magatartására. Az első felmérés egy kecskeméti szupermarket és egy borszaküzlet, valamint egy budapesti borszaküzlet borválasztékának elemzéséböl állt. Több mint 2000 adatot gyüjtöttek az ott található borok típusáról, a fajtákról, árakról, márkákról, származási és eredetvédelmi megjelölésekröl stb. A nők $70 \%$-a az édes és félédes borokat kedveli. A férfiak nem kedvelik az édes bort, de a félédes borok kedveltsége meglehetősen nagy. Ez utóbbi nem több, mint fele a félszáraz és a száraz borokat kedveli. Vásárlási szokásaik alapján 5 csoportba sorolták a borfogyasztókat:

- márkakedvelők

- bortípust kedvelök

- tanácsot kérök

- saját maguk választanak

- nem válogatnak [3]

Kotler kiemeli a bor, mint termék sajátosságait és ehhez igazítja annak marketing feladatait. Hivatkozik azon megállapítására, miszerint a termék alapvetően három tényező együttesével definiálható. Ezek a termék lényegi, formai és hasznosságát növelő tulajdonságok. A lényegi elem az, amit a fogyasztó ténylegesen vásárol, ami azt elkülöníti más termékektöl. Egyúttal azon elönyök összességét is jelenti, melyet a fogyasztó vásárláskor megszerez. A formai tényező az adott termékcsoporton belül olyan sajátosságokat jelent, mint minőségi szint, megkülönböztető jellegzetességek (pl. bouquet, íz, szín stb.), stílus, márkanév, csomagolás stb. A termékhez tartozó 
hasznosságot növelö termék-tulajdonság lehet az ahhoz kötődő plusz szolgáltatások (pl. postai csomagküldés, vásárlás utáni szolgáltatások, tanács-adás, hogyan lehet a legtöbb élvezetet nyerni a termék fogyasztásakor stb.) [2].

Lehota és Tomcsányi a bor marketing-kommunikációjával kapcsolatban egy érdekes amerikai megfigyelést említ, miszerint a borok igen sok változata, fajtája, különféle kiszerelése, évjárata jelenik meg a forgalomban és ezzel a borfogyasztókat a kereskedők gyakran nehéz helyzetbe hozzák. A fogyasztó egy "jó bort" szeretne venni, melyen "inkább hangulatot, mint minőséget ért". Ilyen esetben a reklámnak azt kell sugallania, hogy az adott bor mindenhol megfelel és mindegy hogyan szervírozzák és fogyasztják. A szerző kiemeli annak fontosságát, hogy nem lehet általános érvényű receptet adni a borreklámra vonatkozóan, a mindenkori fogyasztók lélektani beállítottságát kell esetenként felkutatni, megközelíteni és szükség szerint legyőzni [3].

Totth és Szolnoki (2019) összevetik a bort a helyettesítő termékekkel. Itt elsősorban a borsör ill. a bor-üdítő fogyasztás kapcsolatát tekintik át. Magyarországon a sörfogyasztás $30 \%$-kal visszaesett. Ezzel párhuzamosan növekedett a kannás borok fogyasztása. Ez annak a világviszonylatban egyedülálló ténynek köszönhetö, hogy a bor olcsóbb, mint a sör. Az üdítőitalok más szempontból jelentenek konkurenciát. A motorizáció az alkoholfogyasztás ellenében hat. Az üdítőitalok választéka rendkívüli mértékben kiszélesedett [6].

A KGST összeomlása után a keresleti piac kínálati piaccá alakult át és a fogyasztói igények kétpólusúvá váltak. Egyrészt vannak az un. "nagyivók", akik az olcsó borokat fogyasztják. Ők a szegényebb fogyasztói rétegböl kerülnek ki és mindig előteremtik az alkoholra valót. Ezek a fogyasztók alacsonyabb iskolázottságúak. A jövő szempontjából fontosabb másik kategória a "minőségi fogyasztók" csoportja. Ök igényesebbek, megbízható minőséget várnak el. Ök magasabb iskolai végzettségüek, a középosztályhoz tartoznak. Bort ajándékba, ünnepi asztalra vásárolnak. Megfigyelhető itt a márkahüség. Sajnos az életszínvonal romlása ebben a csoportban a minőségi bor fogyasztásának ellenében hat.

Magyarországon az édes, vagy legalább félédes bor kedvelt. Megnőtt a vörösbor iránti igény, mely tartós tendenciának tűnik.

\section{Anyag és Módszer}

Jelenlegi tanulmányunkban a vizsgált 102 ill. 174 fős populáció direkt kérdőíves megkérdezéssel nyert válaszainak segítségével aránybecslést és ezen arányok 95\% konfidenciaintervallumainak kiszámítását alkalmaztuk a hallgatók borfogyasztási szokásainak elemzésére. Ez a típusú becslés statisztikailag megbízhatóbb eredményekre vezet, mint a pontbecslés. "P(A)" vagyis egy "A" esemény valószínüsége az az érték, mely körül a megfigyelt esemény relatív gyakorisága ingadozik, vagyis ha "n" megfigyelésböl az "A" esemény "k"-szor következett be, akkor "k/n" relatív gyakoriságot felhasználhatjuk "P(A)" becslésére, de természetesen ennek értéke ha újabb kísérletet végzünk mindig más és más lesz. Ezenkívül semmit sem árul el arról, hogy nagy valószínüséggel mekkora tartományban ingadozhat ez a becsült érték. Ezért informatívabb sok esetben számunkra olyan intervallum megadása, melyben nagy valószínűséggel benne található a becsült $p=P(A)$ paraméter.

\section{Eredmények}

A két ország azonos korú és érdeklödésű célcsoportjai közötti borfogyasztás különbsége nem tekinthető szignifikánsnak.

A lengyel fiataloknál a borfogyasztás gyakorisága lényegesen elmarad a magyarországi fiatalokétól. Ha a nemeket hasonlítjuk össze, azt látjuk, hogy a lengyel fiúk esetében a havonta ritkábban történő borfogyasztás gyakorisága a legnagyobb, mely szignifikánsan gyakoribb a napi és a heti gyakoriságnál. Napi gyakoriság előfordulása a lengyel fiatalok esetében nulla. A lengyel diáklányoknál gyakorlatilag ugyanez a jelenség figyelhető meg.

Ezekhez némileg hasonló a magyar diáklányok fogyasztási gyakorisága, azzal a különbséggel, hogy a havonta történő borfogyasztási gyakoriság a legnagyobb. A magyar fiú diákok hetente fogyasztanak bort. Egyedül ebben a borfogyasztói kategóriában jelenik meg a napi borfogyasztási 
gyakoriság. Ennek gyakorisága azonban kicsi és havonta ritkábban történő borfogyasztási gyakorisággal együtt szignifikánsan elmarad a gyakoriságuk a heti borfogyasztási gyakoriságtól.

A lengyel fiatal férfiaknál a félédes bor a legkedveltebb, mely szignifikánsan különbözik az összes többi íztípustól, kivéve a félszáraz kategóriát. A két ízvéglet legkevésbé preferált. Fiatal diák-lányok esetében hasonló eredményre jutottunk, azzal a különbséggel, hogy a félszáraz és félé-des kategóriák, bár egymástól nem, a száraz és az édes kategóriáktól mindkettő kedveltsége szignifikánsan különbözik. Miután a diáklányok számaránya nagyobb a mintán belül, a relatív gyakoriság minimum és maximum tartományai is közelebb találhatóak egymáshoz. Ez is előidézhette a szignifikáns különbségek ilyetén módon történő változását.

Magyar férfi hallgatók körében a száraz bortípus a legkedveltebb, ez az édes ízkategóriától szignifikáns eltérést mutat. Magyar diáklányok esetében az édes bor a kedveltebb, de szignifikáns különbségekröl itt nem beszélhetünk.

A két ország azonos nemü hallgatóit összehasonlítva azt látjuk, hogy a magyar fiúk szignifikánsan jobban kedvelik a száraz borokat és kevésbé kedvelik a félszáraz borokat. A két édesebb kategóriában a különbség nem szignifikáns.

Hölgyek esetében a félszáraz borok kedveltsége szignifikánsan nagyobb, mint a magyar hölgyeké. A többi borkategóriában eltérés nem tapasztalható.

Összefoglalóan megállapítható, hogy a lengyel fiatalok az édesebb bortípusokat kedvelik. A magyar diákoknál az íz-preferencia fiúknál a szárazabb, lányoknál az édesebb irányba tolódik, míg a lengyel diákok nemtöl függetlenül a félszáraz és félédes borokat kedvelik.

\section{Következtetések}

Meglepő módon a lengyel fiatalok között nem kisebb azon fiatalok aránya, akik bort fogyasztanak. Ez egy marketing lehetőséget jelent a magyar borimportőrök számára. A fogyasztási gyakoriság azonban rávilágít arra, hogy a borfogyasztás növelése területén bőven van mit tenni.

A száraz és az édes borok kevésbé kedveltek a lengyel fiatalok körében, mint a félszáraz és a félédes.

A lengyel fiatalok körében az óvilági francia és olasz bortermelök borai a legkedveltebbek. A magyar borok a kedveltebb borok közé tartoznak.

A bort nem fogyasztók között nincs lényeges különbség abból a szempontból, hogy miért nem isznak bort. Egyedül a lengyel absztinens diáklányok utasítják vissza következetesen az alkohol, így a bor fogyasztását is.

\section{Köszönetnyilvánítás}

Köszönettel tartozunk a kutatás támogatásáért, amely az EFOP-3.6.2-16-2017-00012 „Funkcionális, egészséges és biztonságos élelmiszer termékpálya modell kidolgozása a szántóföldtől az asztalig elv alapján, tematikus kutatási hálózatban” pályázat keretében valósult meg. A projekt a Magyar Állam és az Európai Unió támogatásával, az Európai Szociális Alap társfinanszírozásával, a Széchenyi 2020 program keretében valósul meg.

\section{Irodalomjegyzék}

[1] Anson J. (2015): French wine consumption shows signs of life - survey, Decanter (www.decanter.com)

[2] Kotler P. (2006): Marketingmenedzsment, Akadémia Kiadó, Budapest, ISBN: 963-05-8345-3 https://doi.org/10.1556/9789630597784

[3] Lehota J.- Tomcsányi P. (1994): Agrármarketing, Mezőgazda Kiadó, Budapest, ISBN: 9789638439239

[4] Levitt T. (2006): On marketing, A Harward business Press, ISBN: 1422102068

[5] Oszoli Á. (et al), (2003): Borfogyasztási szokások Magyarországon (Tanulmány) AMC Kht. - FVM SzBKI Kecskemét, $162 \mathrm{pp}$.

[6] Totth G, - Szolnoki G. (2019) : A magyarországi borfogyasztói szokások és a borpiac elemzése, Gazdálkodás, 63. évfolyam • 1. szám, 2019 (22-39) 